\title{
Video Article \\ Generation and Labeling of Murine Bone Marrow-derived Dendritic Cells with Qdot Nanocrystals for Tracking Studies
}

\author{
Maria Muccioli ${ }^{*}$, Michelle Pate ${ }^{\star^{2}}$, Omowaleola Omosebi ${ }^{2}$, Fabian Benencia ${ }^{1,2,3}$ \\ ${ }^{1}$ Molecular and Cell Biology Program, Ohio University \\ ${ }^{2}$ Department of Biomedical Sciences, College of Osteopathic Medicine, Ohio University \\ ${ }^{3}$ Department of Biomedical Engineering, Russ College of Engineering and Technology, Ohio University \\ * These authors contributed equally
}

Correspondence to: Fabian Benencia at benencia@oucom.ohiou.edu

URL: https://www.jove.com/video/2785

DOI: doi:10.3791/2785

Keywords: Immunology, Issue 52, Dendritic cells, Qdot nanocrystals, labeling, cell tracking, mouse

Date Published: 6/2/2011

Citation: Muccioli, M., Pate, M., Omosebi, O., Benencia, F. Generation and Labeling of Murine Bone Marrow-derived Dendritic Cells with Qdot Nanocrystals for Tracking Studies. J. Vis. Exp. (52), e2785, doi:10.3791/2785 (2011).

\section{Abstract}

Dendritic cells (DCs) are professional antigen presenting cells (APCs) found in peripheral tissues and in immunological organs such as thymus, bone marrow, spleen, lymph nodes and Peyer's patches ${ }^{1-3}$. DCs present in peripheral tissues sample the organism for the presence of antigens, which they take up, process and present in their surface in the context of major histocompatibility molecules (MHC). Then, antigen-loaded DCs migrate to immunological organs where they present the processed antigen to T lymphocytes triggering specific immune responses. One way to evaluate the migratory capabilities of DCs is to label them with fluorescent dyes ${ }^{4}$.

Herewith we demonstrate the use of Qdot fluorescent nanocrystals to label murine bone marrow-derived DC. The advantage of this labeling is that Qdot nanocrystals possess stable and long lasting fluorescence that make them ideal for detecting labeled cells in recovered tissues. To accomplish this, first cells will be recovered from murine bone marrows and cultured for 8 days in the presence of granulocyte macrophagecolony stimulating factor in order to induce DC differentiation. These cells will be then labeled with fluorescent Qdots by short in vitro incubation. Stained cells can be visualized with a fluorescent microscopy. Cells can be injected into experimental animals at this point or can be into mature cells upon in vitro incubation with inflammatory stimuli. In our hands, DC maturation did not determine loss of fluorescent signal nor does Qdot staining affect the biological properties of DCs. Upon injection, these cells can be identified in immune organs by fluorescent microscopy following typical dissection and fixation procedures.

\section{Video Link}

The video component of this article can be found at https://www.jove.com/video/2785/

\section{Protocol}

\section{Dissection of mouse femurs and tibiae and culture of bone marrow cells}

1. Sacrifice 2 mice by $\mathrm{CO}_{2}$ asphyxiation and carefully dissect tibias and femurs without cutting the bone ends.

2. Clean the bones from all the attached tissues by using tissue paper. Be careful not to break the bones.

3. Sterilize the bones by immersion in $70 \%$ ethanol for $10 \mathrm{~min}$ in a $35 \mathrm{~mm}$ Petri dish. From this moment, work inside a biosafety hood to avoid contamination of the cell cultures.

4. Recover the bones from the ethanol and let them air dry for 5 min in a Petri dish inside the biosafety cabinet.

5. Cut the femurs in half, and the tibia by its thinnest tip. Infuse the inside of the bone with $1 \mathrm{ml}$ of RPMI medium (without serum but with antibiotics) using a sterile syringe on a sterile Petri dish.

6. The cell suspension is collected and washed $2 X$ in RPMI medium by 10 min centrifugation in a $15 \mathrm{ml}$ centrifuge tube at $1,100 \mathrm{RPM}$ in a refrigerated centrifuge $\left(4^{\circ} \mathrm{C}\right)$ with a swinging bucket rotor.

7. After the last wash, resuspend the cells in $2 \mathrm{ml}$ of ACK lysis buffer and incubate for $5 \mathrm{~min}$ at room temperature in order to eliminate red blood cells.

8. Add $13 \mathrm{ml}$ of RPMI with $10 \%$ FBS, resuspend and wash $2 \mathrm{X}$ in this medium with the same settings as described in 1.6 .

9. Count cells, adjust to $2 \times 10^{5}$ cells/ml with RPMl $10 \%$ FBS, and add $\mathrm{rm}-\mathrm{GM}-\mathrm{CSF}(20 \mathrm{ng} / \mathrm{ml} \text { final concentration })^{5}$.

10. Add $10 \mathrm{ml}$ of this suspension to a sterile, microbiological quality, $10 \mathrm{~cm}$ Petri dish, and culture in a $\mathrm{CO}_{2}$ incubator $\left(37^{\circ} \mathrm{C}, 5 \% \mathrm{CO}_{2}\right)$

11. Three days later, add another $10 \mathrm{ml}$ of RPMI $10 \% \mathrm{FBS}$ with $20 \mathrm{ng} / \mathrm{l}$ of rmGM-CSF to each of the prepared plates.

12. Three days later $10 \mathrm{ml}$ of cell suspension are recovered from each Petri dish, centrifuged as in 1.6, resuspended in the same volume of RPMI $10 \%$ FBS with rmGM-CSF and returned to the Petri dish. Cells are cultured for 2 additional days in the $\mathrm{CO}_{2}$ incubator. 


\section{Collection and labeling of DCs}

1. After 8 days in culture loosely adherent cells are recovered by washing the Petri dishes with fresh medium. This protocol renders around $2-4$ $x 10^{8} \mathrm{DCs}$ in our hands. Cells can be analyzed for DC phenotype by flow cytometry.

2. Collected cells are then labeled with the Qtracker 655 Cell Labeling Kit strictly following the manufacturer's instructions

3. We got excellent results labeling murine bone marrow-derived DCs with Qdots at a $10 \mathrm{nM}$ concentration. To accomplish this, aliquots of Qtracker Cell Labeling Kit components A and B are mixed in equal volumes, incubated for 5 min at room temperature, and immediately diluted $1 / 100$ in fresh medium with vortexing for $30 \mathrm{~s}$.

4. To stain $5 \times 10^{6} \mathrm{DCs}$, mix $5 \mu \mathrm{l}$ of each kit components $A$ and $B$ in an eppendorf tube and incubate for $5 \mathrm{~min}$ at room temp. Then, add $1 \mathrm{ml}$ of RPMI 10\% FBS incubate, and vortex for 30 second.

5. Add $0.5 \mathrm{ml}$ of cell suspension containing $5 \times 10^{6} \mathrm{DCs}$, and incubate at $37^{\circ} \mathrm{C}$ for $60 \mathrm{~min}$.

6. Then, wash cells $2 X$ in RPMI $10 \%$ FBS (1,100 RPM). Cells can be resuspended in RPMI for further culture or in PBS for injection in experimental mice.

\section{Evaluation of labeled DC}

1. Cell labeling can be evaluated by means of fluorescent microscopy. To accomplish this, a drop of cell suspension is added to a microscope slide, covered with a glass coverslip, and evaluated with a fluorescent microscope taking into account that these Qdots have emission and excitation spectra of $565 \mathrm{~nm}$ and $405-525 \mathrm{~nm}$ respectively (Fig. 3)

2. At this point, the labeled cells can be used to inject animals, or maturation can be induced by incubating these cells for $48 \mathrm{~h}\left(37^{\circ} \mathrm{C}, 5 \mathrm{CO}_{2}\right)$ in the presence of LPS $(100 \mathrm{ng} / \mathrm{ml})$ and TNF- $(20 \mathrm{ng} / \mathrm{ml})$. Fluorescent labeling is not affected by DC maturation (Fig. 4).

\section{Representative Results:}

Herewith we described how to prepare murine bone marrow-derived DCs and how labeled them with fluorescent Qdots. Fig. 1 summarizes the procedure to obtain the cell, while Fig. 2 depicts the procedure to label them with Qdots. As shown in Fig. 3, almost all the cells are labeled by this procedure, and this is not affected by DC maturation with inflammatory factors (Fig. 4). Fig. 5 shows that Qdot-stained DCs (Fig.5a) behave similar to non-stained cells when treated with an inflammatory cocktail. Both cell preparations similarly upregulate expression of costimulatory molecules (Fig. 5b); and produce similar amounts of IL-6 (Fig. 5c) and nitric oxide (Fig. 5d) upon maturation stimuli. This agrees with previous published data indicating that Qdot staining does not affect the capability of $D C$ to turn into mature cells capable of eliciting immune responses [6]. These cells can then be used for injecting experimental animals. As shown in Fig. 6, 2 days after intravenous injection of labeled DCs into mice, we were able to detect Qdot-stained cells in the spleen. This is also in agreement with previous published data showing the use of Qdot nanocrystals to evaluate migration of DC in vivo [6] by non-invasive imaging and flow cytometry.

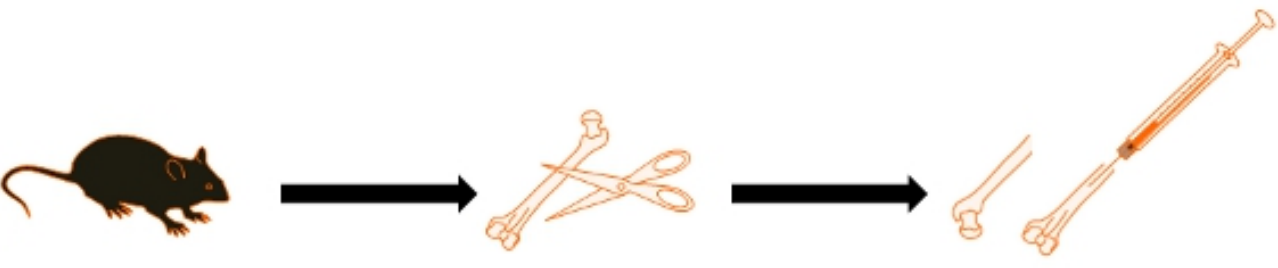

Tibias and femurs are excised
Femurs are cut in half
Bone marrows are flushed with medium

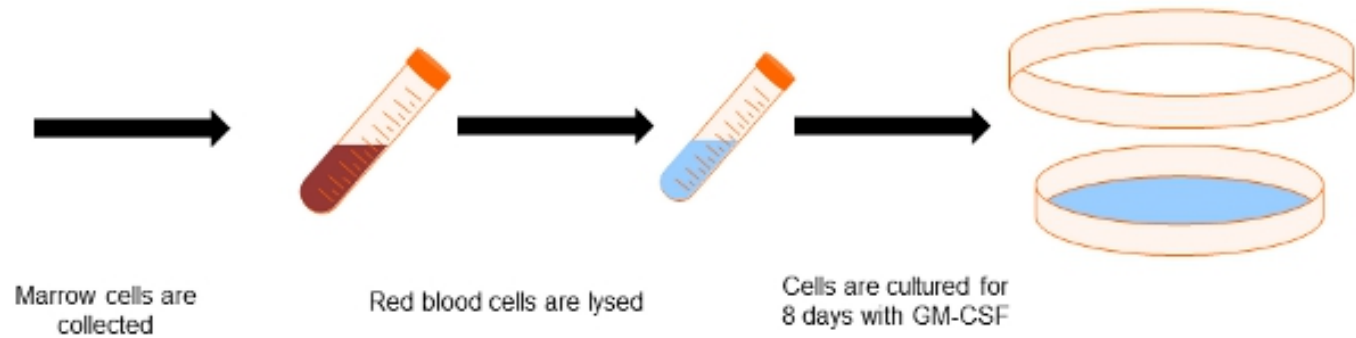

Figure 1. Flow chart of DC generation from bone marrow. Herewith we depict the process to obtain bone marrow-derived DC. Both tibias and femurs are dissected and clean from surrounding tissue. Bone tips are preserved and the interior of the bones are flushed with medium. After eliminating red blood cells, bone marrow cells are cultured for 8 days in the presence of GM-CSF to differentiate them into DCs. 


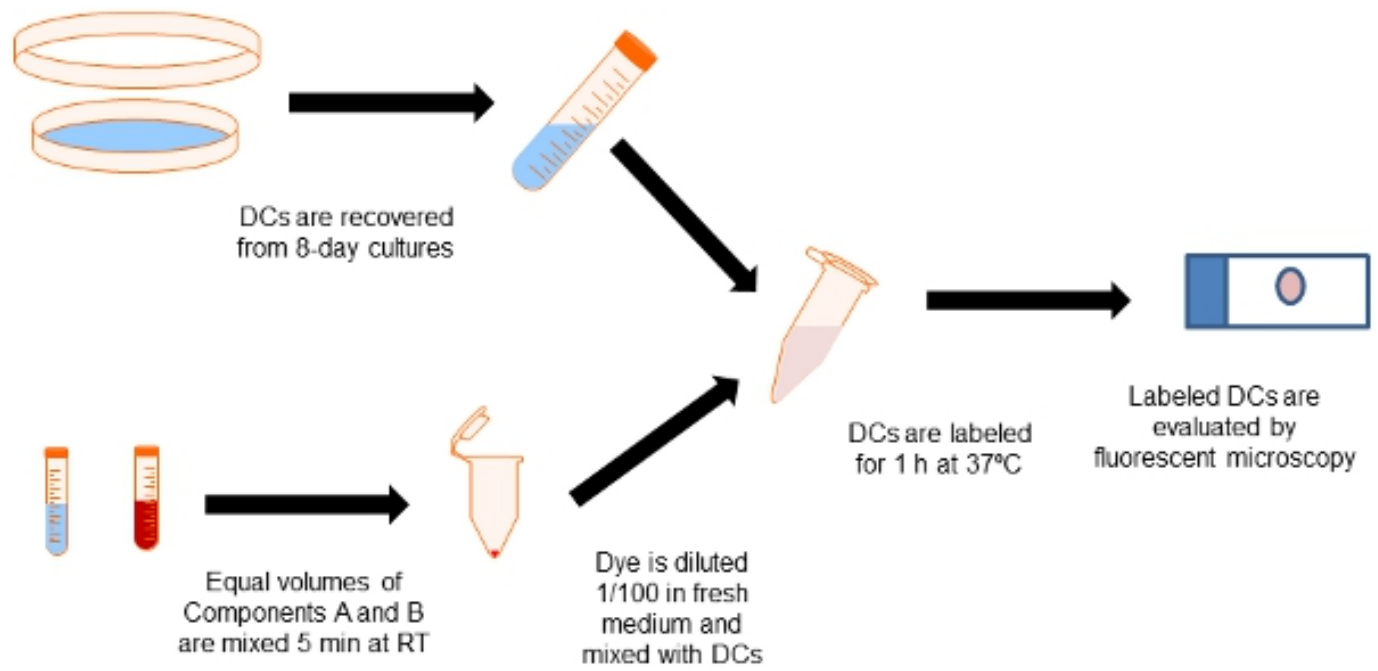

Figure 2. Flow chart of the labeling procedure. Equal aliquots of Qtracker Cell Labeling Kit components $\mathrm{A}$ and $\mathrm{B}$ are mixed in an eppendorf tube. Dendritic cells are collected from 8-day bone marrow cultures with GM-CSF and mixed with the labeling dye for 60 min at $37 \mathrm{C}$. Then cells are washed in media to eliminate excess labeling particles.

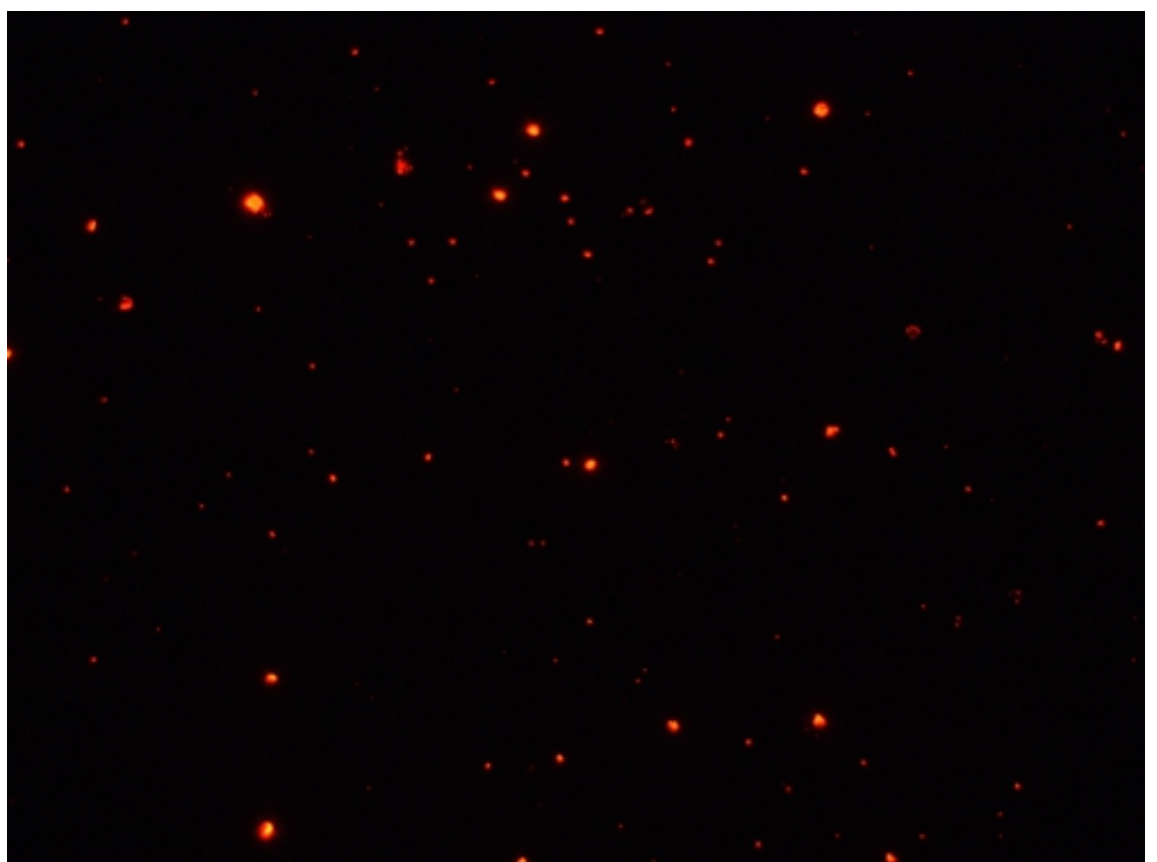

Figure 3. Fluorescent microphotography of DCs immediately after labeling. A drop of labeled cells was deposited on a glass slide and covered by a coverslip. Then, samples were evaluated in a fluorescence microscope and images were acquired through a Micropublisher 5.0 Digital $C C D$ Color Camera (Qimaging, Surrey, BC Canada). 


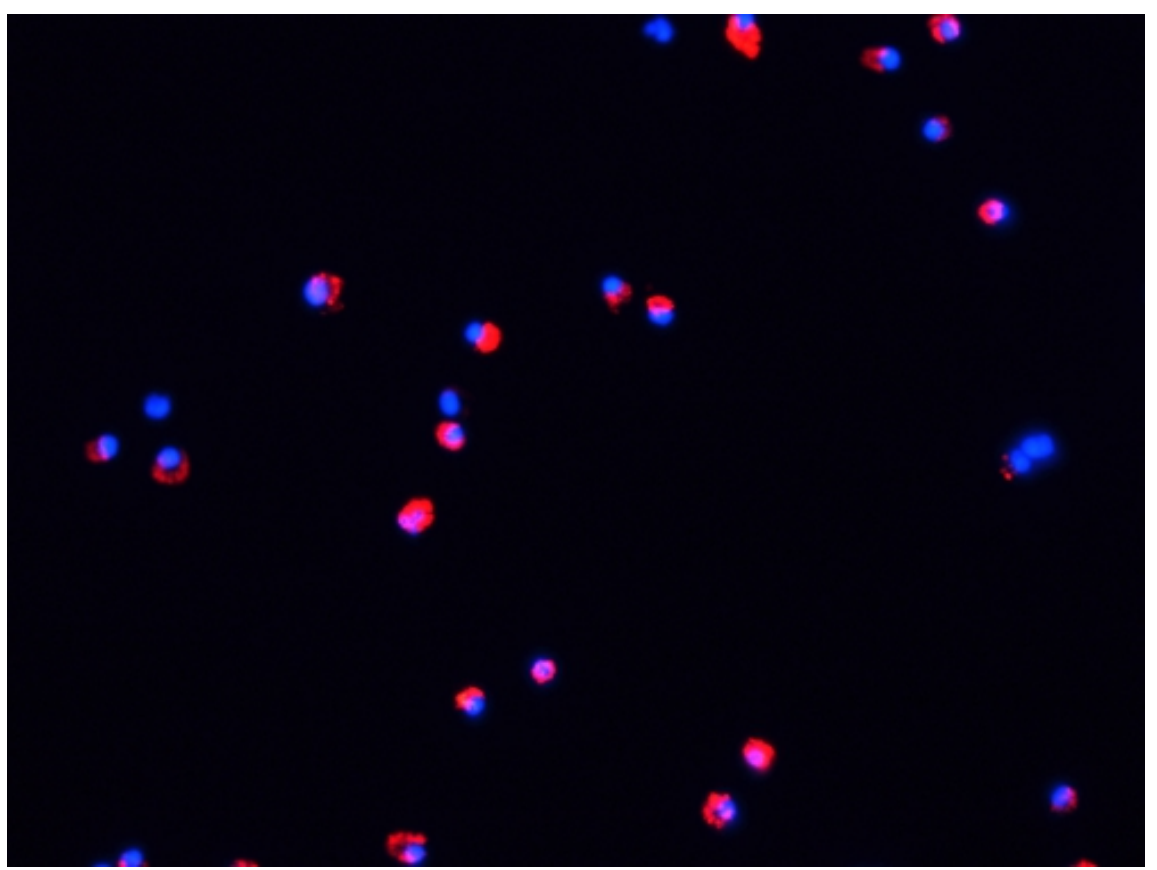

Figure 4. Fluorescent microphotography of DCs after $48 \mathrm{~h}$ maturation in vitro. Labeled DCs were cultured for $48 \mathrm{~h}$ with LPS (100 $\mathrm{ng} / \mathrm{ml})$ and TNF- $\alpha(20 \mathrm{ng} / \mathrm{ml})$ on glass slides on a $\mathrm{CO}_{2}$ incubator $\left(37^{\circ} \mathrm{C}, 5 \% \mathrm{CO}_{2}\right)$. Then, samples were washed with PBS $(5 \mathrm{~min}, 2 \mathrm{X})$, fixed with acetone $(15$ min, $4^{\circ} \mathrm{C}$ ) and counterstained with DAPI. Cells were evaluated in a fluorescent microscope as above.

A

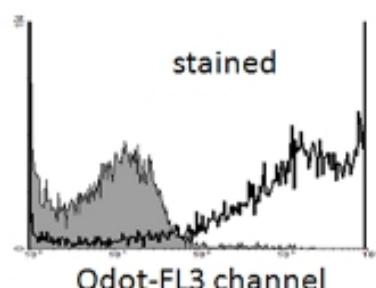

Qdot-FL3 channel
B

CD40

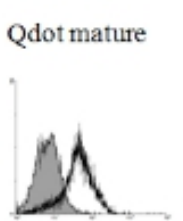

CD86

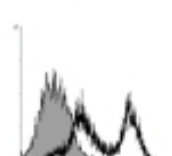

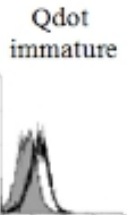

Unstained
mature

Unstained immature
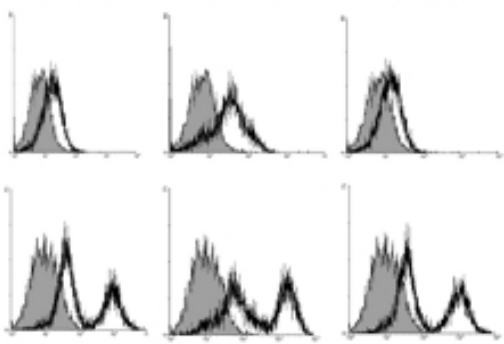
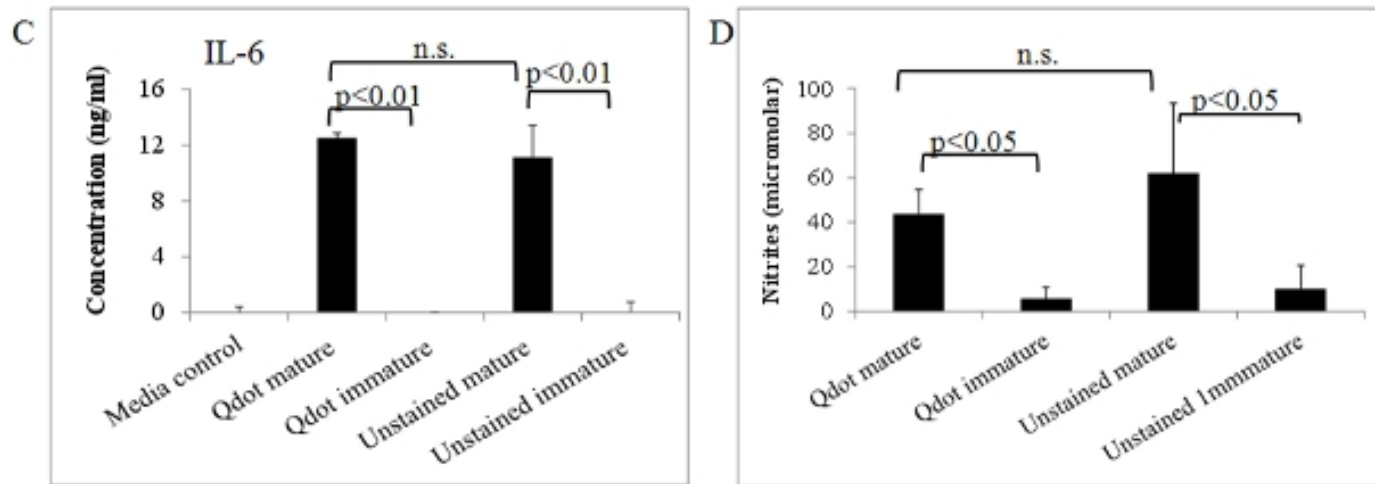

Figure 5. Biological activity of Qdot stained mature DCs. Labeled DCs matured in vitro as above were analyzed by flow cytometry (A) and (B). (A) Qdot-stained cells give a strong signal in the FL3 (PercP) channel. Shaded histogram: unstained control. (B) Qdot-stained and unstained DCs were additionally stained with specific antibodies against maturation markers CD86 and CD40; and isotype controls. Cells were then analyzed in a FACSort flow cytometer (Becton Dickinson, San Jose, CA). Additionally, IL-6 (C) and nitric oxide (NO) were determined in supernatants of mature Qdot-stained DCs and controls. Levels of IL-6 and nitric oxide were determined by means of ELISA analysis and Griess assay as we have previously described ${ }^{7,8}$. All the data showed in this figure is representative of two or three independent experiments showing similar results. Data was analyzed by ANOVA by using the GraphPad software. 
A

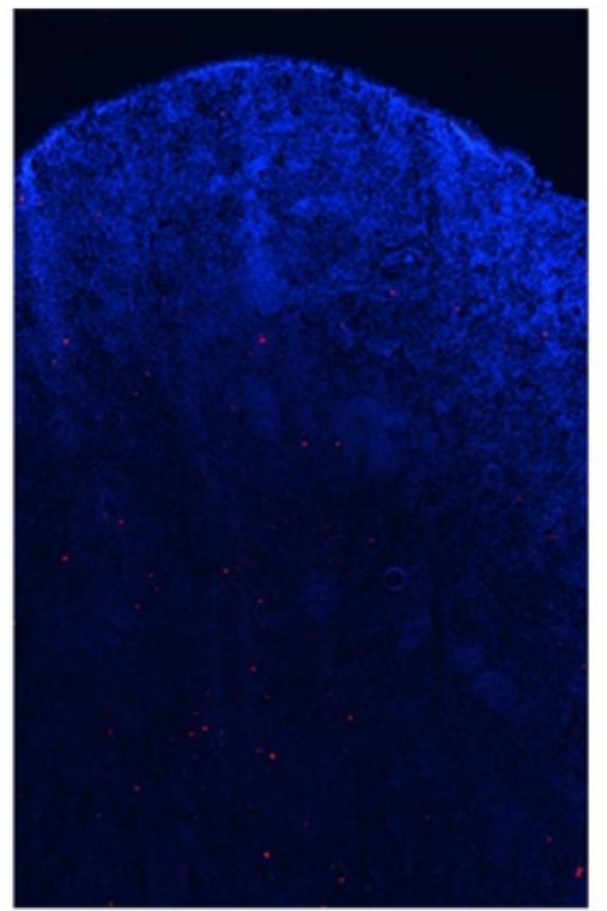

B

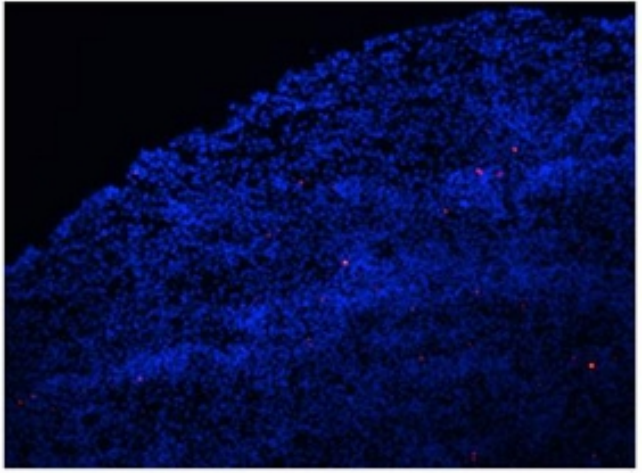

$\mathrm{C}$

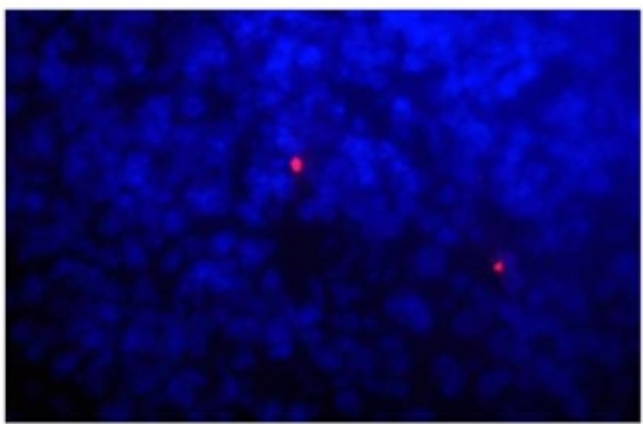

Figure 6. Detection of labeled DCs in dissected tissues. Labeled mature DCs $\left(1 \times 10^{6}\right.$ cells $)$ were intravenously injected into C57BL/6 mice. (A) Two days later mice were sacrificed and spleens collected, snap frozen, embedded in OCT, and $8 \mu \mathrm{M}$ sections prepared using a cryostat. Then, samples were fixed with acetone $\left(15 \mathrm{~min}, 4^{\circ} \mathrm{C}\right)$ and counterstained with DAPI. Cells were evaluated in a fluorescent microscope as above. Fig 6a: 40X magnification, Fig 6b: 100X magnification, Fig. 6C, 400X magnification.

\section{Discussion}

Murine myeloid) DCs have been extensively used in order to determine the efficacy and improvement of DC-based vaccines; investigate DC:T cell interactions or DC development; and determine their role in various diseases ${ }^{9-11}$. Herewith we show how to generate DCs from precursors recovered from bone marrows of tibias and femurs. We recover the bones without cutting the tips, allowing us to sterilize them by submersion in ethanol $70 \%$, thus reducing the probability of contamination. To differentiate DCs from bone marrow cells we only use GM-CSF as previously described ${ }^{5}$. Although some protocols also use IL-4, it has been reported that this cytokine is not necessary when working with high levels of $\mathrm{GM}-\mathrm{CSF}^{12}$. Indeed, we have previously demonstrated that these DCs are able to induce immune responses ${ }^{13}$. Also, care has to be taken to recover only loosely adherent cells from 8-day cultures by washing the Petri dishes with medium since attached cells show a more monocytelike phenotype. Here we show the labeling of DCs with fluorescent Qdot particles. This labeling has some advantages respect to other methods. First, the Qdots particles are easily incorporated into the cells. Second, the fluorescent signal is very high and is not altered by DC maturation. Third, the fluorescence is not lost when cells or tissues are fixed with solvents such as acetone, contrary to what happens if GFP is used to tag DCs ${ }^{14}$, giving more flexibility at the moment to choose staining protocols. Finally, the high fluorescent signal given by these particles allows visualization of the cells despite tissue auto-fluorescence. As previously described ${ }^{6}$, Qdot staining did not affect the maturation capability of these cells. Herewith we show that Qdot-stained DCs behave in a similar way as non-stained DCs, upregulating costimulatory molecules, and producing IL-6 and nitric oxide in response to inflammatory stimuli. Although DCs are cells specialized in triggering immune responses, they have been shown to participate in pathological conditions such as cancer and atherosclerosis ${ }^{4,15,16}$. They have been also claimed to participate in angiogenic process ${ }^{17,18}$, even suggested as structurally participating in the developing of new vessels ${ }^{19,20}$. Thus, methods that allow for DC tracking in vivo, and determining their geographical localization in different tissues ${ }^{4,21,22}$ are very valuable.

\section{Disclosures}

No conflicts of interest declared.

\section{Acknowledgements}

This work supported in part by the NIH under Grant R15 CA137499-01 (F.B.) and a startup fund from Ohio University (F.B.).

References

1. Banchereau, J., Briere, F., Caux, C., Davoust, J., Lebecque, S., Liu, Y.J., Pulendran, B., Palucka, K. Immunobiology of dendritic cells. Annu Rev Immunol 18 : 767-811 (2000).

2. Bonasio, R., von Andrian, U.H. Generation, migration and function of circulating dendritic cells. Curr Opin Immunol 18 : 503-511 (2006). 
3. Lanzavecchia A, Sallusto F: The instructive role of dendritic cells on T cell responses: lineages, plasticity and kinetics. In Curr Opin Immunol 13 291-298 (2001).

4. Conejo-Garcia, J.R., Benencia, F., Courreges, M.C., Kang, E., Mohamed-Hadley, A., Buckanovich, R.J., Holtz, D.O., Jenkins, A., Na, H., Zhang, L., et al. Tumor-infiltrating dendritic cell precursors recruited by a beta-defensin contribute to vasculogenesis under the influence of Vegf-A. Nat Med 10 : 950-958 (2004).

5. Lutz, M.B., Kukutsch, N., Ogilvie, A.L., Rossner, S., Koch, F., Romani, N., Schuler, G. An advanced culture method for generating large quantities of highly pure dendritic cells from mouse bone marrow. J Immunol Methods 223 : 77-92 (1999).

6. Noh, Y.W., Lim, Y.T., Chung, B.H. Noninvasive imaging of dendritic cell migration into lymph nodes using near-infrared fluorescent semiconductor nanocrystals. Faseb J 22 : 3908-3918 (2008).

7. Benencia, F., Courreges, M.C., Conejo-Garcia, J.R., Mohamed-Hadley, A., Zhang, L., Buckanovich, R.J., Carroll, R., Fraser, N., Coukos, G. HSV oncolytic therapy upregulates interferon-inducible chemokines and recruits immune effector cells in ovarian cancer. Mol Ther $12: 789-802$ (2005)

8. Franco, L.G., Feledi, C.A., Massouh, E.J., Benencia, F. Aminoguanidine administered during the induction of oral tolerance alters the systemic response of the tolerised rats. Cell Immunol, $261: 42-50$.

9. Gilboa, E., Vieweg, J. Cancer immunotherapy with mRNA-transfected dendritic cells. Immunol Rev 199 : $251-263$ (2004).

10. Grolleau-Julius, A., Abernathy, L., Harning, E., Yung, R.L. Mechanisms of murine dendritic cell antitumor dysfunction in aging. Cancer Immunol Immunother 58 : 1935-1939 (2009).

11. Yrlid, U., Svensson, M., Johansson, C., Wick, M.J. Salmonella infection of bone marrow-derived macrophages and dendritic cells: influence on antigen presentation and initiating an immune response. FEMS Immunol Med Microbiol 27 : $313-320$ (2000).

12. Lutz, M.B., Schnare, M., Menges, M., Rossner, S., Rollinghoff, M., Schuler, G., Gessner, A. Differential functions of IL-4 receptor types I and II for dendritic cell maturation and IL-12 production and their dependency on GM-CSF. J Immunol 169 : $3574-3580$ (2002)

13. Benencia, F., Courreges, M.C., Coukos, G. Whole tumor antigen vaccination using dendritic cells: comparison of RNA electroporation and pulsing with UV-irradiated tumor cells. J Transl Med $6: 21$ (2008)

14. Probst, H.C., Tschannen, K., Odermatt, B., Schwendener, R., Zinkernagel, R.M., Van Den Broek, M. Histological analysis of CD11c-DTR/ GFP mice after in vivo depletion of dendritic cells. Clin Exp Immunol 141 : 398-404 (2005).

15. Fainaru, O., Adini, A., Benny, O., Adini, I., Short, S., Bazinet, L., Nakai, K., Pravda, E., Hornstein, M.D., D'Amato, R.J., Folkman, J. Dendritic cells support angiogenesis and promote lesion growth in a murine model of endometriosis. Faseb $\mathrm{J} 22: 522-529$ (2008).

16. Bobryshev, Y.V., Lord, R.S., Rainer, S., Jamal, O.S., Munro, V.F. Vascular dendritic cells and atherosclerosis. Pathol Res Pract 192 : 462-467 (1996).

17. Nakai, K., Fainaru, O., Bazinet, L., Pakneshan, P., Benny, O., Pravda, E., Folkman, J., D'Amato, R.J. Dendritic cells augment choroidal neovascularization. Invest Ophthalmol Vis Sci 49 : 3666-3670 (2008).

18. Huarte, E., Cubillos-Ruiz, J.R., Nesbeth, Y.C., Scarlett, U.K., Martinez, D.G., Buckanovich, R.J., Benencia, F., Stan, R.V., Keler, T., Sarobe, P., et al. Depletion of dendritic cells delays ovarian cancer progression by boosting antitumor immunity. Cancer Res 68 : $7684-7691$ (2008).

19. Fernandez Pujol, B., Lucibello, F.C., Zuzarte, M., Lutjens, P., Muller, R., Havemann, K. Dendritic cells derived from peripheral monocytes express endothelial markers and in the presence of angiogenic growth factors differentiate into endothelial-like cells. Eur $\mathrm{J}$ Cell Biol 80 : 99-110 (2001).

20. Gottfried, E., Kreutz, M., Haffner, S., Holler, E., lacobelli, M., Andreesen, R., Eissner, G. Differentiation of human tumour-associated dendritic cells into endothelial-like cells: an alternative pathway of tumour angiogenesis. Scand J Immuno/ 65:329-335 (2007).

21. Bobryshev, Y.V., Lord, R.S. Mapping of vascular dendritic cells in atherosclerotic arteries suggests their involvement in local immune-inflammatory reactions. Cardiovasc Res $37: 799-810$ (1998).

22. Bobryshev, Y.V., Lord, R.S. Co-accumulation of dendritic cells and natural killer T cells within rupture-prone regions in human atherosclerotic plaques. J Histochem Cytochem 53 : 781-785 (2005). 